\title{
The Relationship of Physical Fitness and Academic Achievement of Urban School Students in Malaysia
}

\author{
Ismail E., Razak M. R. A., Alam N. A. M., Bakar A. Y. A.* \\ Faculty of Education, Universiti Kebangsaan Malaysia, Malaysia
}

Received June 27, 2020; Revised August 7, 2020; Accepted August 28, 2020

\section{Cite This Paper in the following Citation Styles}

(a): [1] Ismail E., Razak M. R. A., Alam N. A. M., Bakar A. Y. A. , "The Relationship of Physical Fitness and Academic Achievement of Urban School Students in Malaysia," Universal Journal of Educational Research, Vol. 8, No. 10, pp. 4723- 4727, 2020. DOI: 10.13189/ujer.2020.081042.

(b): Ismail E., Razak M. R. A., Alam N. A. M., Bakar A. Y. A. (2020). The Relationship of Physical Fitness and Academic Achievement of Urban School Students in Malaysia. Universal Journal of Educational Research, 8(10), 4723- 4727. DOI: 10.13189/ujer.2020.081042.

Copyright $\bigcirc 2020$ by authors, all rights reserved. Authors agree that this article remains permanently open access under the terms of the Creative Commons Attribution License 4.0 International License

\begin{abstract}
Physical fitness is a factor which influences academic achievement. The purpose of this study is to know the relationship of physical fitness towards academic achievements (sciences subject) among the female students in the district of Petaling Jaya, Selangor. This is a descriptive study utilizes a comparative data analysis method. The respondents involved were 357 female students; 177 students were 16 years old and the remaining 180 students were 17 years old. Data was gathered from Standard Kecergasan Fizikal Kebangsaan Untuk Murid Sekolah Malaysia (SEGAK) evaluation, and later was compared to the respondents' year-end Science examination results. The findings show that the respondents' body mass index is in a normal range of physical fitness level $(\mathrm{M}=3.74, \mathrm{SD}=.795)$, whereas their Science examinations results were satisfying in the category of credit or grade $\mathrm{C}(\mathrm{M}=7.04, \mathrm{SD}=2.660)$. There was a significant relationship between the physical fitness test using the 3-minute step test and the flexibility of performing academically in the Science subject which is $\mathrm{r}=.226, \mathrm{p}>0.01$ and $\mathrm{r}=.159, \mathrm{p}<0.01$. The finding shows that their cardiovascular endurance and flexibility have influence on their academic achievements, particularly in the Science subject. The results of this study could be used by teachers and school administrators to improve physical fitness programs at school for the benefits of the students.
\end{abstract}

Keywords Academic Achievement, Physical Fitness, Science, Urban School, Malaysia

\section{Introduction}

Academic achievement is one particular aspect foregrounded by most people. The current education is based on 21st-century learning which gives attention to the Higher Order Thinking Skills (HOTS). The Ministry of Education in Malaysia (2019) also stresses on facilitating the 21 st century learning to ensure that education of all levels would excel.

Academic achievement plays a vital role in helping to mold students for the future as well as other factors. Physical fitness is one of many factors that can exert influence on an individual's academic excellence achievement. High cardiorespiratory fitness is salient to intensify the health and academic achievement influence on both children and adolescents (Marques, Santos, Hillman \& Sardinha, 2017). The group of obese people also has an unfit level of fitness which gives consequences to their mental function and academic achievement (Morita et al., 2016). Many studies state that there are correlations between the level of physical fitness, physical activity, and academic achievement (Bezold et al., 2014; Howie \& Pate, 2012).

Academic achievement is said to be in line with physical fitness which is normally associated with physical activity. Inefficacious amount of physical activity leads to obesity, health problems as well as academic achievement (USDHHS, 2010). Physical activity plays an important role to boost academic achievement through the psychological aspects of health, lifestyle, and change in thinking skills as 
well as support learning and cognitive function (Mura et al., 2015: Khan \& Hilman, 2014). Academic achievements are said to be individual solutions and competencies derived from skills, knowledge or progress that are not dependent on the intelligence of the mind (Carter, 1973). Academic performance and physical fitness should be balanced equally. Physical activity that can increase the level of physical fitness is like exercising, where it provides many health benefits. Spending time doing Moderate to Vigorous Physical Activity (MVPA) in a daily activity for duration of 100 minutes can help reduce the risk of death, cardiovascular disease, and heart disease (Basterfield et al., 2008).

The study of Han (2018) found that there was a significant interrelation between the high level of physical fitness and the excellence of academic achievement. Physical fitness is influenced by the efficient and consistent physical activity. Previous studies have shown that there is a positive outcome between physical activity as well as intelligence and in shaping one's mind (Colcombe et al. 2006: Budde et al. 2008: Kwok et. al., 2011). Students who reduce their physical activity by $20 \%$ can reduce their academic performance as well, compared to those who are consistent with their physical fitness level (Bezold et al. 2014).

In conclusion, academic achievement may be an indicator of direct intelligent in school education. However, limited research focuses on the impact of physical fitness on academic achievement in Malaysia. In other words, identifying the relationship between physical fitness and academic achievement will be used in shaping practical education policies and learning methods. Also, it can affect the significance as well as improving physical education and health in schools. Therefore, this study aims to look upon the relationships of physical fitness on academic achievement among students in Petaling Jaya, Selangor.

\section{Research objectives}

The main objective of these study was to study the relationship of physical fitness towards academic achievements (sciences subject) among the female students in the district of Petaling Jaya, Selangor. Other objectives of this study are as follows:

I. To study the level of academic achievement of Science subjects and health of female school students in the district Petaling Utama, Selangor.

II. To study the physical fitness among female students in the district of Petaling Utama, Selangor.

III. To investigate the relationship between physical fitness and the academic achievement of Science subjects.

\section{Methodology}

This is a descriptive study uses a comparative analysis method, whereby the data was gathered via the administration of Standard Kecergasan Fizikal Kebangsaan Untuk Murid Sekolah Malaysia (SEGAK) - a national fitness standard evaluation of school students. The data from SEGAK test was compared to the students' year-end Science examination results. The respondents for this study were the upper secondary students from three all-girl schools in Petaling Jaya district which accumulated to a total of 2,738 students. The number of respondents was determined using formula suggested by Krejcie and Morgan (1970), in which 357 students, aged between 16 to 17 years old, were sampled. These schools were chose because all three had the best Science achievements in the district. The data was collected from SEGAK physical fitness evaluation of 3-minute step test, modified push-up test, sit-up test, and the sit and reach test. This evaluation holistically measures respondents' cardiovascular endurance, muscle endurance, body composition, flexibility, and muscle strength. Overall, the data collection procedure comprised of two main stages namely: 1) the administration of SEGAK evaluation, and 2) the comparison of obtained SEGAK data with the respondents' year-end Science examination results. Data was descriptively and inferentially analyzed, using the Statistical Package for Social Sciences (SPSS) software, version 23.0.

\section{Findings}

There were 177 students, aged 16 years old and the remaining 180 students were 17 years old. The study showed a descriptive analysis that 177 students are 16 years old and 180 students are 17 years old. In terms of racial background, the majority of the 143 students are Malays and the minority of 17 people, are categorized as 'others'. Besides that, the findings showed that 161 people are Muslims, which is the most, whereas another religion is the least which is 8 people. Table 1 shows the demographic background of the study.

The findings of the Body Mass Index (BMI) indicate that the female students are at a normal BMI level and have low health risk value that $\mathrm{M}=2.22 \mathrm{SD}=.757$. $\mathrm{BMI}$ by race shows that the Malays have higher BMI when compare to the other races, that is $\mathrm{M}=2.29, \mathrm{SD}=.777$. In terms of religion, it is shown that Muslim students have a higher normal BMI of $\mathrm{M}=2.30, \mathrm{SD}=.791$. However, in terms of age, 17-year-old pupils had a higher normal BMI than 16-year-old pupils which are $\mathrm{M}=2.25, \mathrm{SD}=.747$. Table 2 shows the BMI for female students as a whole.

Overall, the physical fitness level shows that female students are a moderate stage where $\mathrm{M}=3.74, \mathrm{SD}=.795$. The level of fitness according to race shows that the Chinese are fit than other races, with the value of $\mathrm{M}=3.85$, $\mathrm{SD}=.857$. While the fitness level according to religion shows that Christians had indicated that the value of 
physical fitness fits higher than other religions, namely $\mathrm{M}$ $=3.91 \mathrm{SD}=.777$. In terms of age, 17-year-old female students had a higher physical fitness level compared to 16-year-olds, $\mathrm{SD}=\mathrm{M}=3.77$. 853. Table 3 shows the physical fitness level of female students as a whole.

The academic achievement level of Science subjects showed that students were in the category of failing with $24.6 \%$ compared to other categories. The number of 16-year-old pupils in the failed category was more than the 17-year-old, with value of 47 pupils and 41 pupils respectively. Malay Muslims students in the category of failures are more compared to other races and religions, where there are 35 students and 39 students. Table 4 shows the achievement level of Science subjects achieved by the students.

Table 1. Descriptive analysis of the demographic background of the study

\begin{tabular}{|c|c|c|c|c|}
\hline Item (s) & Frequency $(\mathrm{N})$ & Percent (\%) of & Mean & Standard deviation \\
\hline $\begin{array}{l}\text { Age } \\
16 \text { years old } \\
17 \text { years old }\end{array}$ & $\begin{array}{l}177 \\
180 \\
\end{array}$ & $\begin{array}{l}49.6 \\
50.4 \\
\end{array}$ & 1.50 & .501 \\
\hline $\begin{array}{l}\text { Race } \\
\text { Malay } \\
\text { Chinese } \\
\text { India } \\
\text { Others } \\
\end{array}$ & $\begin{array}{c}143 \\
67 \\
130 \\
17 \\
\end{array}$ & $\begin{array}{c}40.1 \\
18.8 \\
36.4 \\
4.8 \\
\end{array}$ & 2.06 & .977 \\
\hline $\begin{array}{l}\text { Religion } \\
\text { Islam } \\
\text { Buddhist } \\
\text { Hindu } \\
\text { Christian } \\
\text { Others } \\
\end{array}$ & $\begin{array}{c}161 \\
57 \\
99 \\
32 \\
8 \\
\end{array}$ & $\begin{array}{c}45.1 \\
16.0 \\
27.7 \\
9.0 \\
2.2 \\
\end{array}$ & 2.07 & 1.134 \\
\hline
\end{tabular}

Table 2. The level of body mass index for female students

\begin{tabular}{|l|c|c|c|c|c|}
\hline BMI category & Health risk & Frequency (N) & Percent (\%) & Mean & S. D \\
\hline Less weight & High & 40 & 11.2 & & \\
Normal/Ideal & Low & 228 & 63.9 & 2.22 & .757 \\
Overweight & High & 58 & 16.2 & & \\
Obesity & Very high & 31 & 8.7 & & \\
\hline
\end{tabular}

Table 3. The physical fitness among a female students.

\begin{tabular}{|l|c|c|c|c|}
\hline Fitness level & Frequency (N) & Percent (\%) & Mean & S. D \\
\hline Absent & - & - & & \\
Rarely Inactive & 12 & 3.4 & 3.74 & .795 \\
Inactive & 132 & 37.0 & & \\
Moderate & 155 & 43.4 & & \\
Active & 54 & 1.1 & & \\
Rarely Active & 4 & & & \\
\hline
\end{tabular}

Table 4. The achievement level of Science subjects

\begin{tabular}{|l|c|c|c|c|c|}
\hline Category & Grade & Frequency (N) & Percent (\%) of & Mean & S. D \\
\hline Superb & A & 2 & 0.6 & & \\
Excellent & A & 15 & 4.2 & & \\
Brilliant & A & 27 & 7.6 & & \\
Highest Honour & B & 28 & 7.8 & & \\
High Honour & B & 50 & 14.0 & & \\
Top Honour & C & 26 & 7.3 & 7.04 & 2.660 \\
Praiseworthy & C & 39 & 10.9 & & \\
Upon Graduation & D & 30 & 8.4 & & \\
Pass & E & 41 & 24.6 & & \\
Fail & F & 88 & 3.1 & & \\
Absent & Th & 11 & & \\
\hline
\end{tabular}


Table 5. The relationship between physical fitness tests to the achievement level of Science subject

\begin{tabular}{|l|l|c|}
\hline \multicolumn{2}{|c|}{ Fitness Test $(\mathrm{N}=357)$} & Science Achievement \\
\hline \multirow{2}{*}{ 3-minute Step Test } & Pearson Correlation & $.226^{* *}$ \\
& . Sig (2-tailed) & .000 \\
\hline \multirow{2}{*}{ Modified Push-ups } & Pearson Correlation & -.023 \\
& . Sig (2-tailed) & .666 \\
\hline \multirow{2}{*}{ Sit ups } & Pearson Correlation & -.053 \\
\hline \multirow{2}{*}{ Sit and Reach Test } & .Sig (2-tailed) & .314 \\
\hline
\end{tabular}

NOTE: ** Significant relationship at the level of 0.01 (2-tailed)

The relationship between the physical fitness test to the academic achievement of Science subject showed that the 3-minute step test, and the sit and reach test had a significant relationship to the achievement of Science subjects. While the physical fitness test for modified push-up and the sit up has no significant relationship to the achievement level of Science subjects. Table 5 shows the relationship between physical fitness tests to the achievement level of Science subjects.

\section{Conclusions}

The research was conducted to study the relationship of physical fitness towards academic achievements (sciences subject) among the female students in the district of Petaling Jaya, Selangor. Overall, the findings show that there are two physical fitness tests that have a significant relationship to the academic achievement of students in Science subject which are the 3-minute step test (cardiovascular) and the sit and reach test (flexibility).

There is a study said students need to do exercises properly and systematically. The American College of Sports Medicine (ACSM) (2013) advises adolescents to perform physical activity for at least 60 minutes per day to reduce the risk of non-communicable diseases (NCD). For those who are obese or overweight, they should be practicing physical activities for at least three hours per week. By spending more on time watching television, playing video games, and using smartphones, it affects the sedentary lifestyle.

Therefore, a thorough study should be undertaken by researchers in relation to academic achievement and physical fitness, especially in Malaysia, which do not focus on some subjects. In addition, future researchers are advised to review what is associated with the lifestyle and academic achievements. This study is an indirect guide for students, parents, schools, and ministries in developing the welfare of students.

\section{REFERENCES}

[1] American College of Sports Medicine. (2013). ACSM's guidelines for exercise testing and prescription. 2010. Baltimore: Wilson \& Wilson, 8.

[2] Basterfield, L., Adamson, A. J., Parkinson, K. N., Maute, U., Li, P. X., Rehoboam, J. J., \& Gateshead Millennium study Core team. (2008). Supervision of physical activity in the UK is deficient: validation of the health survey for England physical activity questionnaire. Archives of the disease in Childhood, 93 (12), 1054-1058.

[3] Bezold, C. P., Konty, K. J., day, S. E., Berger, M., Harr, L., Larkin, M., \& Stark, J. H. (2014). The effects of changes in physical fitness on academic performance under New York City youth. Magazine for Adolescents Health, 55 (6), 774-781.

[4] Budde, H., Voelcker-Rehage, C., Pietraßyk-Kendziorra, S., riling Ro, p., \& Tidow, G. (2008). Opportunity Coordinative exercise improves attention performance in adolescents. Neuroscience Letters, 441 (2), 219-223.

[5] Cognitive styles on, R. V., \& Morgan, D W. (1970). Determining sample size for research activities. Educational and psychological Measurement, 30 (3), 607-610.

[6] Colcombe, S. J., Erickson, K. I., KwaZulu-Maranta F, P. E., Kim, J. S., et al. (2006). Aerobic exercise training increases the brain volume in aging people. The Journals of Gerontology Series A: Biological sciences and Medical Sciences, 61 (11), 1166-1170.

[7] Donnelly, J. E., Castelli, D., Etnier, J. L., Lee, S., Tomporowski, P., and... Szabo-Reed, A. (2016). Physical activity, fitness, cognitive function, and academic performance in children. Medicine \& Science in Sports \& Exercise, 48 (6), 1197 - 1222.

[8] Han, G.S. (2018). The relationship between physical fitness and academic performance among adolescents in South Korea. Journal of Physical Therapy Science, 30 (4), 605 608. DOI: $10.1589 /$ jdisrupted. 30.605 .

[9] Howie, E. R., \& Pate, R. R. (2012). Physical activity and academic performance in children: a historical 1. Magazine for Sports and Health Science, 1 (3), 160-169.

[10] Khan, A., \& the Man, C. (2014). The ratio of childhood physical activity and aerobic fitness to brain function and cognition: a review. Pediatric Exercise Science, 26 (2), 138-146.

[11] Kwok, T. C., Lamb, K. C., Wong, P. S., Chau, W. W., Yuand, K. S., et al.,(2011). In the best of coordination exercise in improving cognitive function in older adults: a prospective study. Clinical interventions in ageing, 6, 261.

[12] Morita, H., Nakajima, T., Okita, S., Ishihara, T., Sagawa, K., 
\& K. Yamatsu (2016). Relationships under fitness, obesity, screen time and academic performance in Japanese adolescents. Physiology \& Behavior, 163, 161-166.

[13] Mura, G., Vellante, M., Nardi, S. Egidio, Machado, S., \& Giovanni Cards, M. (2015). Effects of school-based physical activity interventions on cognition and academic performance: a systematic review. CNS \& Neurological Disorders-Drug targets, 14 (9), 1194-1208.

[14] Music career, A., Santos, D. T., "See Man, C. L., \& Sardinha, L. B. (2017). How academic performance relates to cardiorespiratory fitness, self-reported physical activity and objective reported physical activity: a systematic review in children and adolescents aged $6-18$ years. British Journal of
Sports Medicine, 52 (16), 1039 - 1039. DOI: 10.1136/bjsports-2016-097361.

[15] Serra-Paya, N., Ensenyat, A., Serra-Paya, p., \& Blanco-Nespereira, A. (2015). Physical activity behavior, aerobic fitness and quality of life in school-age children. Procedia Social and behavioral sciences, 191, 1758-1762.

[16] The Ministry of Education, (2018). National Physical fitness standards for school kids Malaysia (stage PRESENCE).

[17] The US Department of Health and Human Services. (2010). The association between school-based physical activity, including physical education and academic performance. Atlanta, GA. 